Controversies in Pediatric and Adolescent Hematology 


\section{Pediatric and Adolescent Medicine}

\section{Vol. 17}

Series Editors

David Branski Jerusalem

Wieland Kiess Leipzig 


\title{
Controversies in Pediatric and Adolescent Hematology
}

Volume Editors

\author{
Angela E. Thomas Edinburgh \\ Christina Halsey Glasgow
}

13 figures, and 19 tables, 2014

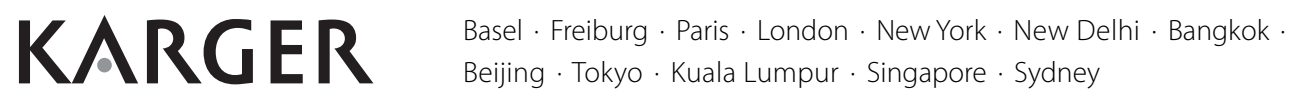


Pediatric and Adolescent Medicine Founded 1991 by D. Branski, Jerusalem

\author{
Angela E. Thomas \\ Consultant Pediatric Hematologist \\ Royal Hospital for Sick Children \\ Edinburgh \\ EH9 1LF
}

\author{
Christina Halsey \\ Consultant Pediatric Hematologist and \\ Scottish Senior Clinical Research Fellow \\ Institute of Infection, Immunity and \\ Inflammation \\ College of Medical, Veterinary and Life Sciences \\ University of Glasgow \\ Glasgow \\ G12 8TA
}

Library of Congress Cataloging-in-Publication Data

Controversies in pediatric and adolescent hematology / volume editors, Angela E. Thomas, Christina Halsey.

p. ; cm. -- (Pediatric and adolescent medicine, ISSN 1017-5989;

vol. 17)

Includes bibliographical references and indexes.

ISBN 978-3-318-02422-7 (hard cover : alk. paper) -- ISBN (invalid)

978-3-318-02423-4 (electronic version)

I. Thomas, Angela E., editor of compilation. II. Halsey, Christina, editor

of compilation. III. Series: Pediatric and adolescent medicine ; v. 17.

1017-5989

[DNLM: 1. Child. 2. Hematologic Diseases. 3. Adolescent. 4. Infant.

W1 PE163HL v.17 2014 / WS 300]

RJ269.5

$618.92^{\prime} 15--d c 23$

2013034474

Bibliographic Indices. This publication is listed in bibliographic services, including Current Contents ${ }^{\circledR}$.

Disclaimer. The statements, opinions and data contained in this publication are solely those of the individual authors and contributors and not of the publisher and the editor(s). The appearance of advertisements in the book is not a warranty, endorsement, or approval of the products or services advertised or of their effectiveness, quality or safety. The publisher and the editor(s) disclaim responsibility for any injury to persons or property resulting from any ideas, methods, instructions or products referred to in the content or advertisements.

Drug Dosage. The authors and the publisher have exerted every effort to ensure that drug selection and dosage set forth in this text are in accord with current recommendations and practice at the time of publication. However, in view of ongoing research, changes in government regulations, and the constant flow of information relating to drug therapy and drug reactions, the reader is urged to check the package insert for each drug for any change in indications and dosage and for added warnings and precautions. This is particularly important when the recommended agent is a new and/or infrequently employed drug.

All rights reserved. No part of this publication may be translated into other languages, reproduced or utilized in any form or by any means electronic or mechanical, including photocopying, recording, microcopying, or by any information storage and retrieval system, without permission in writing from the publisher.

(c) Copyright 2014 by S. Karger AG, P.O. Box, CH-4009 Basel (Switzerland)

www.karger.com

Printed in Germany on acid-free and non-aging paper (ISO 9706) by Kraft Druck GmbH, Ettlingen

ISSN 1017-5989

e-ISSN 1662-3886

ISBN 978-3-318-02422-7

e-ISBN 978-3-318-02423-4 


\section{Contents}

vil Preface

Thomas, A.E. (Edinburgh); Halsey, C. (Glasgow)

1 Neonatal Thrombocytopenia

Chakravorty, S.; Roberts, I. (London)

16 Paediatric and Adolescent Immune Thrombocytopenia: Prevention of Bleeding versus Burden of Treatment

Cooper, N. (London)

30 Thrombosis in Paediatrics: Genetic versus Environmental Risk Factors and Implications for Management

Monagle, P. (Melbourne, Vic.)

42 Hematological Problems in Pediatric Intensive Care

Revel-Vilk, S. (Jerusalem); Cox, P. (Toronto, Ont.); Robitaille, N. (Montréal, Que.);

Blanchette, V. (Toronto, Ont.)

67 New Advances in the Treatment of Children with Hemophilia

Lillicrap, D. (Kingston, Ont.)

81 Myelodysplastic and Myeloproliferative Diseases in Children: Current Concepts Vyas, P. (Oxford)

98 Towards Personalised Medicine in Childhood Acute Lymphoblastic Leukaemia Halsey, C. (Glasgow)

116 Reduced Intensity Conditioning in Paediatric Haematopoietic Cell Transplantation

Chiesa, R.; Veys, P. (London)

135 Can Iron Chelators Replace Stem Cell Transplantation in the Treatment of

Thalassaemia Syndromes?

Darbyshire, P.J. (Birmingham)

151 Iron Deficiency: When and Why Oral Iron May Not Be Enough

Crary, S.E. (Little Rock, Ark.); Buchanan, G.R. (Dallas, Tex.)

161 Principles of Transitional Care in Haematology

Bolton-Maggs, P.H.B.; Choudhuri, S. (Manchester)

172 Author Index

173 Subject Index 



\section{Preface}

The care of infants, children and young people with hematological disorders provides a fascinating and ever changing spectrum of diagnoses, management challenges and treatment dilemmas. In infancy not only does the blood system undergo physiological changes in adaptation to the extra-uterine environment but it is also the time when congenital disease will present often for the first time within a family. During early childhood periods of rapid growth put great nutritional demands on the body and iron deficiency anemia is very common. Throughout childhood, the establishment of an immune repertoire with rapid lymphocyte proliferation in response to infectious challenge may also predispose to autoimmune disorders such as ITP or malignancies such as acute lymphoblastic leukemia. However, it is not only young children that provide challenges - adolescence is a time of great upheaval and there is increasing recognition of the unique needs of patients with lifelong conditions during their transition from pediatric to adult-centered models of care. In this volume, we focus on recent advances in the understanding and treatment of many of these neonatal, childhood and adolescent disorders. We are also delighted to include a chapter on the management of problems that may arise in the intensive care unit - either due to life-threatening presentations of primary hematological disorders or due to hematological responses secondary to significant systemic illness.

Drug therapy for pediatric disorders is particularly challenging, many drugs are unlicensed in children and it is often difficult to extrapolate optimal treatment schedules from adult data. In addition, although children often tolerate toxic treatment for conditions such as leukemia much better than adults, the impact of late effects of treatment can be much greater due to the long life expectancy. This leads to great debate and controversy: How aggressive does the treatment need to be? What are the long-term effects of treatment? Can we tailor treatment more specifically to individuals to maximize benefit while minimizing risk? These questions are addressed in this volume for a spectrum of diseases with some of the controversies moving towards resolution, for the time being at least, and translating into advances in clinical practise. 
We are very grateful to the authors for their expertise and enthusiasm in helping us complete this project in a timely fashion and to the publishers for their help and encouragement with the volume. We hope that you both enjoy the debate and discussion in the book and find it a useful tool for your clinical practise.

Angela E. Thomas, Edinburgh

Christina Halsey, Glasgow 